\title{
The study of ore minerals parageneses in Ponorogo area, East Java
}

\author{
Endang Wiwik Dyah Hastuti ${ }^{1, *}$ \\ ${ }^{1}$ Geological Engeneering Department Faculty of Engeneering, Sriwijaya University, 30128 Palembang, Indonesia
}

\begin{abstract}
The present study was undertaken in the Southern Mountain Range of East Jawa, Ponorogo District. Tectonically, the region extends along the Magmatic Sunda-Banda Arc, which comprises predominantly volcanic rocks of Mandalika Formation, sedimentary rock units of Arjosari Formation, and intrusive sequences such as dacite, andesite and diorite. Structurally, the region is controlled by faults striking NE-SW, NW-SE and N-S. Mandalika Formation and Arjosari Formation have an interfingering relation and are Oligo-Miocene. Results of the field observation and analyses of petrography and mineragraphy on outcrops reveal that the region has commonly undergone alteration and mineralisation. The principle ore minerals occurring in the Ponorogo area are pyrite and sphalerite with abundant mineral assemblages of chalcopyrite, magnetite, hematite, galena, covelite, bornite, and limonite. Mineralisation occurs in argillic zone and subprophyllitic zone. Based on textures, structures and ore mineral assemblages, mineralisation in the study area can be devided at least into two stages. The earlier stage was present in relation to hypogene processes, and resulted in pyrite-sphalerite-chalcopyrite-magnetitegalena. The subsequent stage took place due to supergene enrichment processes, and yielded pyritesphalerite-covelite-bournite-limonite. Such mineral assemblages suggest that they are formed at temperatures of about $100-360^{\circ} \mathrm{C}$.
\end{abstract}

\section{Introduction}

The study area is situated in the southern section of East Java. Physiographically, the region forms part of the Southern Mountain Range of East Java (Fig. 1) [1]. Stratigraphically, it is included in the Old Andesite Formation [2]. The region consists predominantly of rhyolitic and basaltic volcanic rock successions. Geology of this area has been mapped and resulted in the 1:100,000 geological map of the Ponorogo sheet [6] (Fig. 2).

Rock sequences constituting the region consist from oldest to youngest units of Formation Mandalika, comprising volcanic breccias and tuffs, and Arjosari Formation, consisting of sandstones alternating with breccias. These formations show an interfingering relation, and are Oligo-Miocene in ages. The sequence was intruded by andesite, dacite and basalt which resulted in local alteration and mineralization. In addition, the study area has also influenced by volcanic activities during Late Miocene, indicated by the presence of andesitic lava that has experienced weak alteration and mineralization. Figure 2 shows the regional stratigraphic correlation proposed by several workers.

Ore deposits seem to take place in the likely geological controls such as the presence of heat source in the form of magmatism, channel way that fasilitated permeability of rocks, and structures determining the occurring ore pattern [7-9]. The ore mineralization has been controlled by a strike slip fault extending to the NW-SE, NE-SW, and N-S direction (Fig 3). In the mineralized zone, quartz veins are present as veinlet or stockwork and disseminated crystals in both fissure vein and wall rock.

The wall rock mineralization is generally present in volcanic sequences, the Oligocene-Middle Miocene sedimentary rocks, and the Lower-Middle Miocene extrusive successions [10]

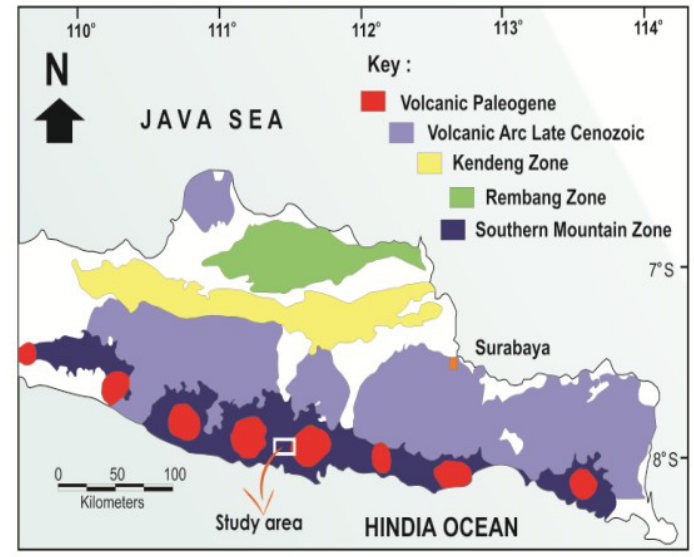

Fig. 1. A map showing physiography of East Java [1] 


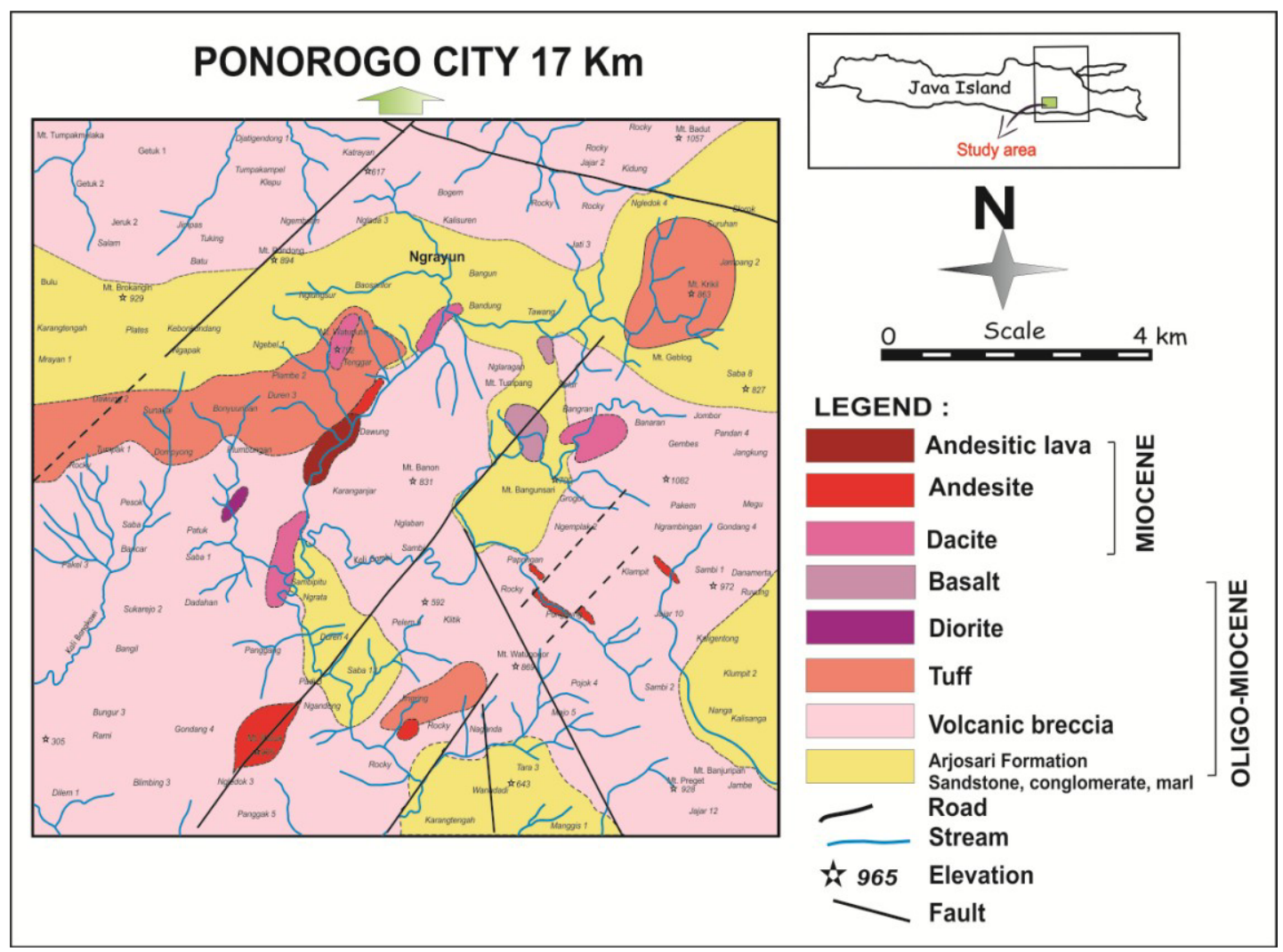

Fig. 2. Geological map of the study area (modified from [3-5]

\section{Samples and methods}

Mineral analysis done by macroscopic and microscopic observation. Determination of mineral in fine grained sizes is done with analysis polishes section. The polished rock thin sections analysis is performed to determine the type of mineral, texture, the relationship between minerals and microscopic characteristics related to the occurrence of ore mineralization as well as paragenesis interpretation. Data polish section done by microscope Zeis, 2000.

Texture formed in mineral deposits vary considerably depending on the characteristics of the fluid, chemical and physical characteristics of the wall rock and the way its deposition [8]. From the appearance of the texture will be able to assist in interpreting the chronologies set precipitated minerals (paragenesis), environment of formation (type deposit) and the way its deposition.

The analysis was performed on 30 samples in the present study were collected from outcrops which have undergone alteration and mineralization. The rocks samples Analysis of the polished rock thin sections was undertaken at one of accredited laboratories available in Bandung.

\section{Mineral characteristics}

Ore minerals recognized in the study area include pyrite, sphalerite, galena, and minor chalcopyrite, magnetite, covellite, and bornite (Fig. 3). Gangue minerals such as feldspar, quartz and clay minerals are common, but calcite, chlorite and muscovite are few, and adularia, actinolite, epidote and pyrophilite are dispersed [10].

Pyrite is the most abundant sulphide mineral in the study area. The occurrence of this mineral can be divided into two generations. The earlier phase resulted in euhedral-subhedral grains ranging from 0.03 to 0.5 $\mathrm{mm}$ in size, generally formed zoning, and associated with sphalerite. The later episode yielded euhedralanhedral pyrites with sizes between 0.01 to $0.2 \mathrm{~mm}$, generally associated with sphalerite and galena in fractures.

Results of petrographic analysis show that pyrite is yellow to white, cubic or euhedral, smooth or rough anhedral, fractured, and brecciated (fragmental). This suggests that the formation of the crystal has a relatively long range. They are commonly present with chalcopyrite and quartz. Under the microscope, mineral pyrite is partially replaced by covelite forming a blanket at the edge of pyrite (Fig. 4A).

Pyrite formed at the early stage or the first magmatic generation. The crystals are subhedralanhedral, and there appears corrosion on the edges, cracking (cataclastic textures), filled in with chalcopyrite, sphalerite, and quartz, and often brecciated with drag patterns. Pyrite is interpreted to be generated prior to deformation of the rock section. 


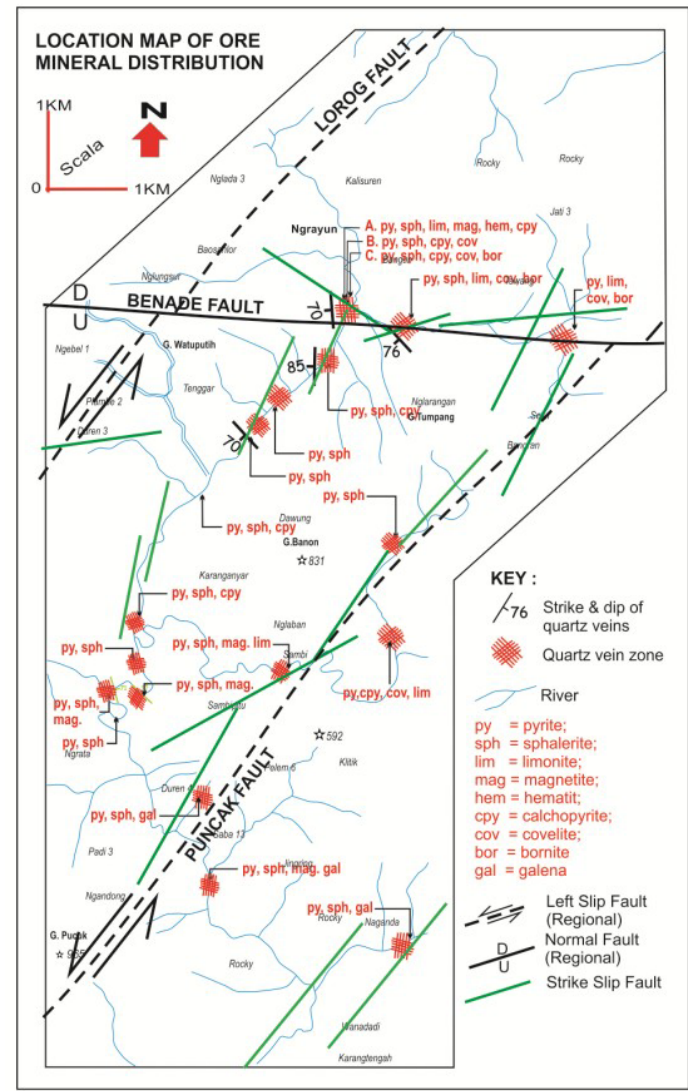

Fig. 3. Location map of ore mineral distribution and structural trend in the study area

Chalcopyrites in the field area is encountered in a moderate amount, present in quartz veins and wall rocks around the intrusive body, and shows subhedral anhedral crystals. This mineral often occurs associated with pyrite and galena (Fig. 4B). Under microscope, chalcopyrites are anhedral in shape with visible cleavage and alteration around the edges. Chalcopyrites are generally existed as crack filling in quartz veins altogether with pyrite and arsenopyrite. Some chalcopyrites grow together with galena, chalcopyrite and quartz. Chalcopyrite in the samples analyzed is wide spread distributed and shows cleavages. The crystal and cleavage of chalcopyrites have undergone alteration into covelites, which have blue-gray color (Fig. 4D) and sphalerite inclution.

Galena is found in small quantities, present in the wall rock and quartz veins, anhedral-euhedral in shape, light gray-white in color, very fine-moderate $(<0.01$ $0.2 \mathrm{~mm}$ ) in size, and appears to be associated with pyrite, chalcopyrite and arsenopyrite. Microscopic appearance on a number of samples shows that galenas are present as inclution in pyrite and chalcopyrite (Fig. 4E), and show textures of triangular facets (Fig. 4F).

Covelite and Bornite, these minerals replace some of pyrite and chalcopyrite, and fracture-filling in pyrite, but it is also present as exsolusion on chalcopyrite. Covellite is the altered chalcopyrite (Fig. 4B). In the field, the crystal is easily observed, blue-gray in color, usually occurs on the margin of chalcopyrite and associates with malachite and bornite. Whereas, bornite is commonly present in quartz veins together with covelite and malachite, brownish-red, and subhedral anhedral.

Magnetite veins are present, distributed and partly replaced by hematite. Some magnetites are dissected by pyrite. This feature indicates that the magnetite was formed ahead of pyrite.

Sphalerite occurs with pyrite and pyrite partially envelop, locally associates with galena (Fig. 4G \& H). It is dark gray in color, fine to medium-sized grain (0.01-0.2 mm), subhedral-anhedral in shape, and partially shows the texture of emulsion.

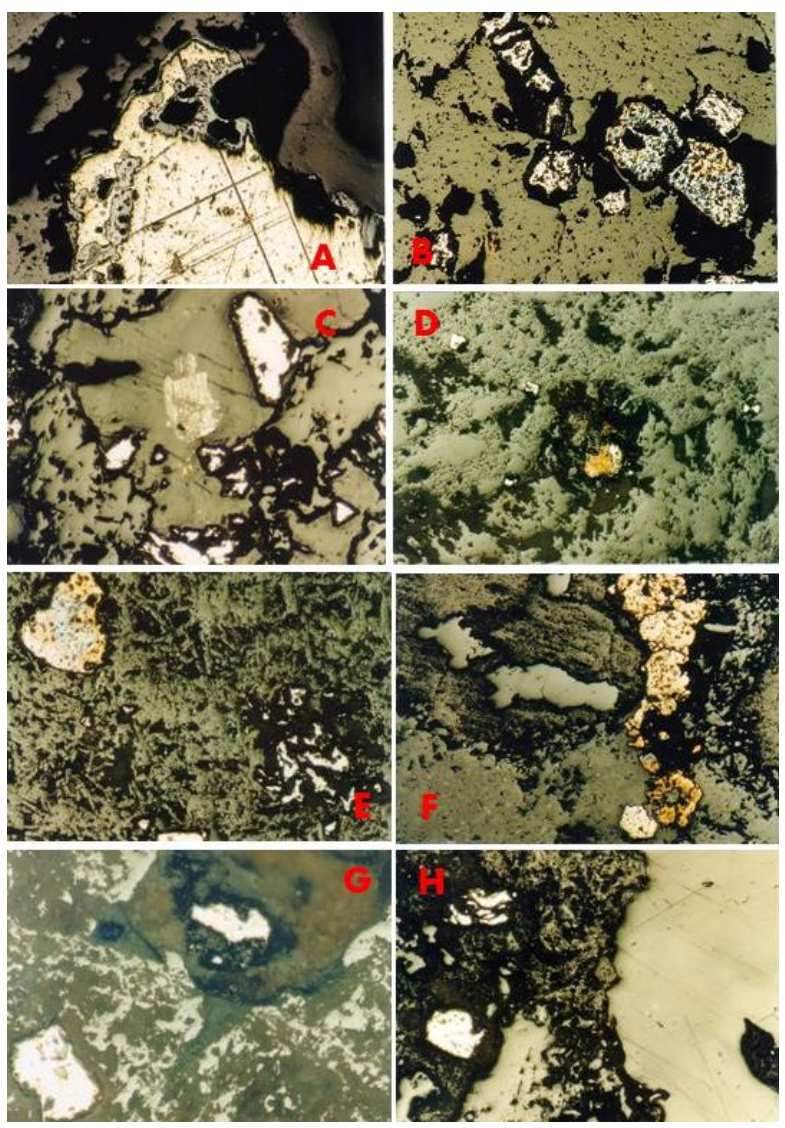

Fig. 4. Photomicrograph of ore minerals poles petrography in the study area showing A. Sphalerite (gray) enveloped by pyrite, displaying texture replacemen; B. Pyrite is partly replaced by covelite (bluish) and bornite (brownish); C. Arsenopyrite shows euhedral in shape and most visible feature is that of corrosion on the edges. D. Sphalerite (gray) largely replaced by chalcopyrite (yellow); E. chalcopyrite (yellow, top left) altered partly into covelit (blue-gray); F. Quartz veins filled by pyrite, and chalcopyrite particularly intruded by sphalerite; G. Sphalerite is an inclusion of pyrite (bottom left); H. galena is present within pyrite (bottom left)

Diginite and chalcocite, both minerals are very rare, form as secondary minerals and replace pyrite and chalcopyrite. Chalcopyrite is mostly covered by digenit.

Gold in the study area is found in quartz veins and wall rock in the form of electrum. In thin section, the mineral occurs together with galena forming emulsion texture and is usually found in fractures and dissiminated on quartz and quartz breccia. Gold is often found in quartz filling fault lines and is very hard 
to see under thin section. This is only found from the essay analysis (0.2-2.7 ppm).

Limonite is an alteration or a secondary mineral, generally comes from pyrite and pyrhotite. The occurrence of the mineral in in the field is relatively easy to be treced through its brownish pink color. Limonites are often found in quartz breccia fractures, reddish yellow in color, usually resulted from dissolved minerals within ore. Under microscopic observation, most of limonite is a kind of goethite that has a cubic shape and shows colloform textures, and contains in the gap between quartz crystals. Limonite is formed due to the oxidation process.

Hematite, under megascophic appearance, it is present in fracture and associated with pyrite. It is estimated that the occurrence of hematite is formed by the oxidation of pyrite. On microscopy observation, hematite is partially replaced by some magnetite.

\section{Fluid inclusion analysis}

Fluid inclusions are a small volume of fluid, microscopic trapped during the formation of a mineral. Based on the genesis, fluid inclusions are divided into two, namely primary and secondary inclusions. Primary inclusions trapped during the formation of a primary crystal, while the secondary inclusions trapped in the fracture-tectonic fractures.

Fluid considered homogeneous phase during the process of entrapment. When the temperature decreases, there is a difference between the shrinkage that traps inclusions and crystal, in which the existence of this shrinkage resulting inclusion becomes more homogeneous with the onset of vapor bubbles and may also appear a crystal in fluid inclusions. Inclusion consisting of fluid and vapor-called biphasic, while containing fluid, vapor and crystals called trifase. The composition of the fluid inclusions could be $\mathrm{CH} 4$, $\mathrm{CO} 2, \mathrm{H} 2 \mathrm{O}$, hydrocarbons and so on

Analysis of the formation temperature quartz veins using methods mikrotermometri research areas, namely the inclusion heat until the steam disappears. In general, the method used is divided into two parts, namely thermometry which include heating fluid inclusions to obtain the homogenization temperature (Th) which is used to determine the formation temperature and kriometri in the form of cooling fluid inclusions for measuring the fusion temperature (Tf) which is used to infer the composition. Analysis of fluid inclusions conducted at the Laboratory of Physics Mineral Research Center for Geotechnology LIPI, assuming that the temperature is measured in quartz veins more or less the same as the minimum temperature at the time of the fluid trapped during the process of the fluid in a state of homogeneous, then the temperature calculated at the time the loss of steam (Th).

The results of measurements of fluid inclusions in the study area indicate that the quartz veins formed at a temperature ranging $164.1^{\circ} \mathrm{C}-293.2^{\circ} \mathrm{C}$ with an average temperature $216.1^{\circ} \mathrm{C}$.
Mikrotermometri measurement is performed only on the primary, measuring more than $5 \mu \mathrm{m}$, subhedraleuhedral shape (Tabel 1).

Tabel 1. Mikrotermometri measurement and calculation results of fluid inclusion analysis

\begin{tabular}{|l|c|c|}
\hline \multicolumn{1}{|c|}{ Parameter } & Kisaran & $\begin{array}{c}\text { Rata- } \\
\text { rata }\end{array}$ \\
\hline $\begin{array}{l}\text { Liquid temperatures } \\
(\mathrm{Tm})\end{array}$ & $-2.1--0.5^{\circ} \mathrm{C}$ & $-1.3^{\circ} \mathrm{C}$ \\
\hline $\begin{array}{l}\text { Homogenisation } \\
\text { temperatures (Th) }\end{array}$ & $164.1-293.2^{\circ} \mathrm{C}$ & $216.1^{\circ} \mathrm{C}$ \\
\hline Salinity Na Cl & $0.9-3.9 \% \mathrm{WT}$ & $2.4 \% \mathrm{WT}$ \\
\hline Depth [11] & $62.83-913.71 \mathrm{~m}$ & $228.82 \mathrm{~m}$ \\
\hline Pressure [11] & $6.85-76.24 \mathrm{bar}$ & $21.28 \mathrm{bar}$ \\
\hline
\end{tabular}

Based on the results of the measurement and calculation of temperature conditions of quartz vein, So that quartz vein in the satudy area form and grow at a depth of $62.83 \mathrm{~m}$ from $913.71 \mathrm{~m}$ and form at temperatures from $293.2{ }^{\circ} \mathrm{C}$ up to $164,1^{\circ} \mathrm{C}$, or included in the epithermal zone [11].

\section{Paragenesis}

Paragenesis is a time sequence during mineral deposition; how many times a mineral deposition has formed [7-9]. Chronology of mineral deposition, called the sequence paragenesa. This study used the term paragenesis to discuss the sequence of mineralization.

Observation on the structure of ore mineral deposits present in stockwork, brecciations, veins, mineral composition and microscopic appearance of texture such as exolusion, charging, replacement, suggest that there are at least two episodes of mineralization. The early episode relates to the mineralization hypogene processes (Tabel 2), while the subsequent episode results in supergene enrichment processes (Tabel 3).

Tabel 2. Temperature range of mineralization in the study area (a range of temperatures taken from [11])

\begin{tabular}{|l|l|l|l|l|}
\hline \multicolumn{5}{|c|}{ Temperature Range of Mineralisation Hypogene $\left(200-360^{\circ} \mathrm{C}\right)$} \\
\hline \multicolumn{3}{|c|}{$0^{\circ} \mathrm{C}$} & \multicolumn{3}{|c|}{$200^{\circ} \mathrm{C}$} & \multicolumn{2}{c|}{$300^{\circ} \mathrm{C}$} & $400^{\circ} \mathrm{C}$ \\
ORE MINERAL & & & & \\
\hline Magnetite & & & & \\
\hline Pyrite & & & & \\
\hline Chalcopyrite & & & & \\
\hline Sphalerite & & & & \\
\hline Galena & & & \\
\hline Bonite & & & \\
\hline Arsenopyrite & & & \\
\hline
\end{tabular}


Tabel 3. Temperature range of mineralization in the study area (a range of temperatures taken from [12])

\begin{tabular}{|c|c|c|c|c|}
\hline \multicolumn{5}{|c|}{ Temperature Range of Mineralisation Hypogene $\left(<125^{\circ} \mathrm{C}\right)$} \\
\hline Ore Mineral 0 & $100^{\circ} \mathrm{C}$ & $200^{\circ} \mathrm{C}$ & $300^{\circ} \mathrm{C}$ & $400^{\circ} \mathrm{C}$ \\
\hline \begin{tabular}{|l|} 
Covelite \\
\end{tabular} & - & & & \\
\hline Bornite & 2 & & & \\
\hline Digenite & 2 & & & \\
\hline Chalcosite & -1 & & & \\
\hline Limonite & -1. & & & \\
\hline
\end{tabular}

In the hypogene zone, ores mineralization formed as a product of rocks reaction with hidrothermal fluid due to oxidation [13]. Therefore, the formation of hypogene mineralization is likely formed at temperatures about $260^{\circ}-360^{\circ} \mathrm{C}$ (Tabel 2). The chronology of hypogene mineralization in the study area is as follows: started by the formation of magnetite that forms magnetite veins and dessimination, followed by other metal sulphide mineralization (pyrite, sphalerite, galena, and chalcopyrite) prior to the formation of magnetite and chalcopyrite. Subsequently, mineralization of sphalerite, galena and chalcopyrite continued until to the end of this episode in conjunction with the formation of bornite.

Enrichment Supergen in the study area is characterized by mineralization digenit-bornitecovellite that replaced part of chalcopyrite and pyrite. Pyrite is the dominant sulphide mineral, suggesting the presence of dissolving agent. According to [8-9] the occurrence of dissolving agent might have formed ferric sulfate, which then reacted with sulfides in the vicinity. Under water $\mathrm{CuSO}_{4}$ would react with primary sulfide and form sulfide supergen.

Ferric hydroxide precipitate changes to form limonite in the oxidation zone. Limonite contained in the study area is largely formed on the fracture. Based on mineral assemblage, supergene mineralization takes place at temperatures less than $125^{\circ} \mathrm{C}$ (Table 4).

Tabel 4.: Paragenesa in the study area

\begin{tabular}{|c|c|c|c|c|}
\hline \multirow{3}{*}{$\begin{array}{l}\text { ORE MINERAL } \\
\text { Magnetite }\end{array}$} & \multicolumn{4}{|c|}{ HYPOGENE $\left(200-360^{\circ} \mathrm{C}\right)$} \\
\hline & $400^{\circ} \mathrm{C}$ & $300^{\circ} \mathrm{C}$ & \multirow{2}{*}{$200^{\circ} \mathrm{C}$} & ${ }^{\circ{ }^{\circ} \mathrm{C}}$ \\
\hline & - & & & \\
\hline Pyrite & & & - & \\
\hline Sphalerite & & & - & \\
\hline Galena & & & $=$ & \\
\hline Chalcopyrite & & - & & \\
\hline Bonite & & & - & \\
\hline \multirow[t]{2}{*}{ Arsenopyrite } & & 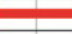 & & \\
\hline & & & & $\begin{array}{c}\text { SUPERGENE } \\
<125^{\circ} \mathrm{C}\end{array}$ \\
\hline Covelite & \multicolumn{4}{|c|}{ 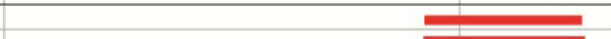 } \\
\hline $\begin{array}{l}\text { Bornite } \\
\text { Disenita }\end{array}$ & \multirow{2}{*}{\multicolumn{4}{|c|}{ 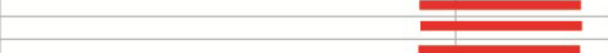 }} \\
\hline Digenite & & & & \\
\hline $\begin{array}{l}\text { Chalcosite } \\
\text { Limonite }\end{array}$ & \multicolumn{4}{|r|}{ 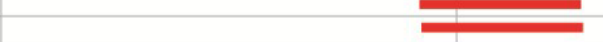 } \\
\hline
\end{tabular}

\section{Conclusion}

Igneous rocks in the study area are generally exposed to follow the pattern of structures. Igneous rocks in the region suffer alteration and mineralization. The event was due to intrusion of igneous rocks which have brought hydrothermal solution. Quartz veins are generally found in old rocks of Oligocene to Lower
Miocene, especially those that have undergone argillic alteration. This indicates that the mineralization occurs from the first episode of magmatic intrusion. Hence, it can be interpreted that the gold was formed at the time of the second breakthrough.

In the study area there are at least two episodes of mineralization. The early episode wes related to the hipogene mineralization, characterized by the formation of magnetite, followed by sulphide mineralization (pyrite, chalcopyrite, sphalerite, galena, bornite and arsenopyrite). The final episode is characterized by supergene enrichment, characterized by the formation of digenit, chalcocite, bornite and covelite. These minerals are formed due to charging and replacement textures as well as little exsolusi.

Base on the fluid inclusion analysis mineralisation in the study area formed at a depth from $913.71 \mathrm{~m}$ to $62.83 \mathrm{~m}$ and at temperatures from $293.2{ }^{\circ} \mathrm{C}$ to $164,1^{\circ} \mathrm{C}$,

The presence of mineral sericite, chlorite, adularia, calcite, chalcopyrite, galena, sphalerite indicates that the possible mineralization environment in the study area is a low sulphidation system.

The author is grateful to the University of Sriwijaya for reseach fund. We also thank my colleagues Edy Sutriyono, who has been involved in finishing this paper especially in editing

\section{References}

1. Sribudiyani; Muhsin, N.; Ryacudu, R.; Kunto, T.; Astono, P.; Prasetya, I.; Sapiie, B.; Asikin, S.; Harsolumakso, A.H.; Yulianto, I. The collision of the East Java microplate and its implication for hydrocarbon occurrences in the East Java Basin. Proceedings Indonesian Petroleum Association.

2. Van Bemmelen, RW. The Geology of Indonesia. Govt. Printed Office, the Haque (1949), V. I p. 545-675. \& V. II p. 92-174

3. Samodra, H.; Gafoer, S.; \& Tjokrosapoetro, S. Peta geologi lembar Pacitan. Jawa. Sekala 1 : 100.000. Puslitbang Geologi. Bandung (1992).

4. Sampurno dan Samodra, H. Peta geologi lembar Ponorogo. Jawa. Sekala 1 : 100.000. Puslitbang Geologi (1997). Bandung.

5. Hartono, U.; Baharuddin; dan Brata, K. Peta geologi lembar Madiun. Jawa, Sekala 1 : 100.000. Puslitbang Geologi (1992). Bandung.

6. Sudarto, T. dan Prapto, A.S. Laporan penyelidikan logam dasar dan logam mulia di daerah Nawangan, Pacitan dan Ngrayun, Ponorogo, Jawa Timur. Direktorat Sumberdaya Mineral (1995). Bandung

7. Corbett, G.J. \& Leach, T.M. Southwest Pacific Rim gold-copper Systems: Structure, alteration and mineralization. Sociaty of Economic Geologists (1995.). Special Publication 6

8. Guilbert, J.M. and Park, C.F., JR. 1986.The Geology of Ore Deposits. W.H. Freeman and Company, New York, p. 55-209 
9. Pirajno, F. Hydrothermal Mineral Deposit. Berlin Heiderberg, Springer - Verlag (1992)

10. Dyah Hastuti, E.W., Suparka, E., Asikin, S., Harsolumakso, A.H. Miocene Volcanism Related to Hydrothermal Alteration in Ponorogo, East Java, Indonesia. Procceding 8th International Congress on Pacific Neogene Stratigraphy, Chiang Mai (2003), Thailand, p. 418-425

11. Haas, J.L. Jr.. The effect of salinity on maximum thermal gradient of a hydrothermal system at hydrostatistic pressure. Economic Geology (1984) 66 : $940-946$.

12. Anonim. Important Hydrothermal Minerals and Their Significance. Sixth Edition, Kingston Morrison Limited (1995), 65 p.

13. H. Leal-Mejía, J. C. Melgarejo, and Draper, Ore Mineral Paragenesis of the Gramalot Gold Deposit, Colombia. Macla, revista de la sociedad española de mineralogía (2008), no. 9. 139-140 